\title{
Sorghum Genetic Resource Collection, Evaluation, Conservation and Utilization in Ethiopia: A Review
}

\author{
Brikti Ferede $^{1^{*}}$, Wondimeneh Taye ${ }^{2}$ \\ Assosa University, Department of Plant Sciences, P.O. Box 18, Assosa, Ethiopia \\ Department of Plant Sciences, College of Agriculture, Wolaita Sodo University, Ethiopia
}

*Corresponding Author: Brikti Ferede, Assosa University, Department of Plant Sciences, P.O. Box 18, Assosa, Ethiopia

\begin{abstract}
Ethiopia is one of the centers of crop origin and diversity in the world. The country is is further believed to be the center of origin such as coffee (Coffea arabica), safflower (Carthamus tinctorius), tef (Eragrostis tef), noug (Guizotia abyssinica), anchote (Coccinia abyssinica), enset (Ensete ventricosum). Very high genetic diversity is found in Ethiopia in four of the world's widely grown food crops (wheat, barley, sorghum and peas); in three of the world's most important industrial crops (linseed, castor and cotton); in the world's most important cash crop (coffee); in a number of food crops of regional and local importance (tef, noug, Ethiopian mustard, enset, finger millet, cowpea, lentil) and in a number of forage species of world importance (clovers, medics, oats). Even though the greatest genetic diversity for both cultivated and wild forms of sorghum is found in Ethiopia, the country has had limited number of collected accessions which cannot represent the total sorghum genetic resource as well as limited success with the utilization of the conserved germplasm. Hence the review was aimed at providing perspectives on the current status of sorghum genetic resource collection, evaluation, conservation, regeneration and utilization. This would be very useful information for future research and genetic improvement of the crop.
\end{abstract}

Keywords: Ethiopia, genetic diversity, germplasm, sorghum

\section{INTRODUCTION}

Plant genetic resources are defined as the "Genetic material of plants that is of value as a resource for the present and future generations of people" (IPGRI 1993). The importance of genetic resources was recognized at the intergovernmental platform under the umbrella of the Food and Agriculture Organization of the United Nations as the "common heritage of mankind" which should be made available without restriction (FAO 1983 cited in Reddy et al., 2006).

Sorghum [Sorghum bicolor (L.) Moench] has an immense range of genetic variability available in Africa most likely Ethiopian-Sudan border where domestication first occurred. Further diversity occurred in Asia due to the early introduction of the crop. Landraces and wild relatives of cultivated sorghum from these centers of diversity are rich sources of resistance to diseases, insect pests and other stresses such as high temperature and drought. They are also sources of traits to improve food and fodder quality, animal feed and industrial products. However, this natural genetic diversity is under threat due to the destruction of habitats, commercial agricultural practices, industrial and infrastructural activities, and large-scale adoption of improved cultivars. Collection and conservation of sorghum germplasm has been accelerated in the past four decades to prevent the extinction of landraces and wild relatives of cultivated sorghum. Since then, germplasm collection and conservation have become integral components of crop improvement programs at both national and international levels (Reddy et al., 2006).

Germplasm collections have provided original materials for plant breeding program and crop improvement. Because of their genetic diversity and possible occurrence of particular desirable genes, germplasm collections are useful targets for plant breeders as well as other biologists. Recently, many of germplasm are being lost worldwide due to habitat destruction, invasion of foreign species, and reliance on fewer high yielding strains. Therefore, maintaining germplasm of agricultural crops is very important. Nowadays, countries all over the world have set up facilities for conservation, 
characterization and utilization of germplasm collections of various crops either directly or indirectly (Hoa, 2010).

A centralized collection of sorghum in Ethiopia began at the Jimma Agricultural Technical School, now Jimma University between 1958 and 1960 (Rosenow and Dalhberg 2000). In the early 1970s, the Ethiopian Sorghum Improvement Project (ESIP) began the collection, evaluation, documentation and conservation of germplasm. Through the early 1980s Ethiopian sorghum improvement project had amassed a collection of approximately 5500 accessions. It is estimated that through continued research efforts, the germplasm has grown to roughly 8000 collections (Rosenow and Dalhberg 2000). The distinct types of sorghum from Ethiopia are (1) zera zeras, (2) durras and (3) durra-bicolor derivatives. The zera zeras have been extremely useful in providing germplasm for the improvement of food type sorghums. Currently the number of sorghum accessions available in Institute of Biodiversity reaches nearly 10,000 (IBC, 2007).

Ethiopia has a diverse wealth of sorghum germplasm adapted to a range of altitudes and rainfall conditions. The crop is mainly grown in the lowland arid and semiarid areas. Of the five morphological races of sorghum (bicolor, guinea, caudatum, durra, and kafir) all except kafir are grown in Ethiopia. Important traits reported from Ethiopian sorghum include cold tolerance, drought resistance, resistance to sorghum shoot fly, disease and pest resistance, grain quality and resistance to grain mould, high sugar content in the stalks, and high lysine and protein content (IBC, 2007).

\section{Global Status of Sorghum Genetic ResourceS}

Sorghum genetic resources are conserved at many centers around the world. At the global level, sorghum germplasm collections consist of approximately 168,500 accessions. The major organizations/countries which maintain sorghum genetic resources are the International Crops Research Institute for the Semi-Arid Tropics (ICRISAT), Patancheru, Andhra Pradesh, India, the National Plant Germplasm System (NPGS) in USA, Ethiopia, Sudan, South Africa, India and China, primarily because they have large crop improvement programs (Reddy et al., 2006). One of the largest collections (about $22 \%$ of the global total) is held at ICRISAT.

ICRISAT is a major repository for world sorghum germplasm with a total of 36,774 accessions from 91 countries. The collection is estimated to represent about $80 \%$ of the variability present in sorghum (Eberhart et al., 1997). Landraces constitute $85.3 \%$, breeding material $13.2 \%$, wild species accessions $1.2 \%$ and named cultivars $0.3 \%$ of the total collection. The germplasm maintained at ICRISAT consists of five basic races: bicolor, guinea, caudatum, kafir and durra and their 10 hybrid races. However, the collection is predominantly represented by three races: durra (23.5\%), caudatum (20.6\%) and guinea (14.8\%). Of the 10 hybrid races, only three, durra-caudatum (11.5\%), guineacaudatum (9.2\%) and durra-bicolor (7.1\%) are common. India, Uganda and Zimbabwe have all the five basic and ten hybrid races (Reddy et al. 2002). Guinea-caudatums, durra and their hybrid races are well-represented in Ethiopia, and caudatum and its hybrid races in Sudan.

\subsection{Sorghum Genetic Resources in Ethiopia}

Ethiopia is one of the richest genetic resource centers in the world in terms of crop diversity. Sorghum is among the four crops widely grown food crops in the world (wheat, barley, sorghum and peas). Very high sorghum genetic diversity is found in Ethiopia. It is widely grown in the country, in 13 of the 18 major agro-ecological zones, covering over 1.3 million hectares. Ethiopian Biodiversity Institute is a major repository for sorghum germplasm with a total of 9772 accessions from different agro-ecological zones of the country. Ethiopia has a diverse wealth of sorghum germplasm adapted to a range of altitudes and rainfall conditions. The crop is mainly grown in the lowland arid and semiarid areas. Of the five morphological races of sorghum (bicolor, guinea, caudatum, durra, and kafir) all except kafir are grown in Ethiopia. Important traits reported from Ethiopian sorghum include cold tolerance, drought resistance, resistance to sorghum shoot fly, disease and pest resistance, grain quality and resistance to grain mould, high sugar content in the stalks, and high lysine and protein content (IBC, 2007).

Sorghum is one of the traditional crops that is well utilized by the crop improvement programmes in the country. Accessions have so far been evaluated for the highlands and intermediate elevations, where the indigenous landraces are widely cultivated. Developing varieties for lowland areas depends on introduction and evaluation of materials from exotic sources owing to the low diversity associated 
with recurrent drought and stalk borer in the Ethiopian germplasm. For the highlands where there is immense diversity, the emphasis has been on the evaluation of indigenous germplasm. To date, the national and regional research institutions in Ethiopia have released about 37 varieties for commercial production (MoA, 2012). Six of the varieties on the current recommendation list were developed from local sources (IBC, 2007).

\subsubsection{Germplasm Collection}

The fundamental objective of collecting plant genetic resource is to capture the maximum amount of genetic variation in the smallest number of samples (Marshall and Brown 1975). The development of efficient strategies depends on the extent of available information on the type of genetic variation in target taxa populations and their distribution in the target geographical region. However, when there is lack of information on the target species and the collection area it might be prudent to organize an exploration mission to collect such information (Allard 1970).

The collections held at Ethiopian Biodiversity Institute are mostly of indigenous landraces, including unique breeders' collections. There are also some accessions that were repatriated from countries that hold large quantities of genetic material in Ethiopia, some of which are not seen today in the fields of farmers. Over the years, a number of collection missions have been organized to collect economically important crops and/or with rich genetic diversity. These include crops like wheat, barley, maize, tef, sorghum, noug, linseed, lupin, finger millet, haricot bean, field pea, lentil and horse bean. Because many times these were threatened by severe drought. The current holdings of the Ethiopian Biodiversity Institute gene bank reach over 60,000 accessions (increased by 6000 the past ten years) of more than $200 \mathrm{crop} /$ plant species. Some collections are in the medium term storage mainly due to insufficient seed sample; these are pending for long term storage (IBC, 2007).

Currently the Ethiopian Biodiversity Institute has collected and maintained 9772 sorghum germplasm accessions. Most of the accessions are landraces, which have acquired under diverse agro-ecological conditions and complex farming systems (Abe, 2010). Before 20 years ago (1983) the numbers of sorghum accessions were 5000 each represented 4000 seeds.

Table1. Collected sorghum accessions based on their geographic distribution in Ethiopia Gene bank

\begin{tabular}{|c|c|c|}
\hline Region & No. of accessions & $\%$ \\
\hline Arsi & 96 & 0.2 \\
\hline Bale & 18 & 2.5 \\
\hline Eritrea & 236 & 4.2 \\
\hline Gamugofa & 403 & 2.2 \\
\hline Gojjam & 207 & 3.8 \\
\hline Gonder & 366 & 8.5 \\
\hline Hararge & 812 & 4.1 \\
\hline Illubabor & 394 & 1.4 \\
\hline Keffa & 129 & 14.2 \\
\hline Shewa & 1350 & 0.9 \\
\hline Sidamo & 94 & 12.2 \\
\hline Tigray & 1163 & 1.6 \\
\hline wellega & 156 & 8.9 \\
\hline Wello & 843 & 34.2 \\
\hline Unknown & 3263 & 99.9 \\
\hline Total & 9530 & \\
\hline
\end{tabular}

Source (Beyene and Theo van, 2006)

\subsubsection{Core Collection}

Although several subsets of total base collection were developed for utilization by sorghum scientists, they turned out to be location-specific and did not give a fair representation of the base collection (Prasada Rao et al. 1995). Therefore, the concept of "core collection" was used to set up a "core collection'. A core collection consists of a limited set of accessions derived from an existing germplasm collection, chosen to represent the genetic and geographical spectrum of the whole collection. The rationale behind a core collection is the maintenance of as much genetic diversity as possible within a smaller, more manageable representative "core collection" (Dahlberg and Spinks 1995). Following this concept, a core collection set up at Institute of Biodiversity in collaboration 
with ICRISAT by stratifying the total base collection geographically and taxonomically into subgroups within regions. Accessions in each subgroup were further clustered into closely related groups. Representative accessions from each cluster were drawn in proportion to the total number of accessions present in that subgroup. Thus, the core collection represents approximately $10 \%$ of the total accessions collection. The core collection is an economical, practical and effective method for conservation, maintenance and utilization of the germplasm (Reddy et al., 2006).

\subsection{Germplasm Evaluation}

Germplasm is evaluated for growth traits, agronomic performance, yield and responses to biotic and abiotic stresses using visual observations and measurement on standard scales. Molecular and biochemical markers (such as isozymes and DNA markers), which are neutral to environment variation may also be used for evaluation. Evaluation is primarily carried out by germplasm users, in multidisciplinary teams that include breeders, entomologists, pathologists and agronomists. The potential value of the germplasm depends on the efficiency of the techniques designed to differentiate accessions. Since farmers possess valuable traditional knowledge and are the ultimate users of the finished products of crop improvement programs, it is advantageous to involve farmers and consider their views and expectations during germplasm evaluation (FAO, 1996).

Since sorghum is grown throughout Ethiopia, which genetically varies extensively, evaluation of germplasm is pre-requisite for the utilization of the available diversity in the crop improvement programme. Hence, it is very important to assess genetic diversity based on quantitative and qualitative traits and identifying promising accessions for different traits that could be utilized in breeding programmes (Abe, 2010).

Diversity studies have been carried out in the Ethiopian, which, like most areas, is threatened by loss of landraces due to introduction and development of improved varieties. Ethiopian sorghum germplasm is noted worldwide as a source of useful genes such as high lysine content, cold tolerance, good grain quality, and disease and insect resistance (Yilma, 1991). Evaluating genetic diversity of germplasm can assist to distinguish accessions with the greatest novelty which thus, is most desirable for incorporation into crop improvement programmes. Molecular markers help to identify suitable germplasm for incorporation into future plant breeding programmes. Hence, assessment of genetic diversity in sorghum germplasm and determination of sorghum phenotypic and biochemical activities would help to know the breeding potential of the accessions in Ethiopia (Abe, 2010).

Estimation of genetic diversity to identify groups with similar genotypes is important for conserving, evaluating and utilizing genetic resources, for studying the diversity of different germplasm as possible sources of genes that can improve the performance of cultivars, and for determining the uniqueness and distinctness of the phenotypic and genetic constitution of genotypes. A comparison of the different methods of the estimation of genetic diversity is important to evaluate their utility as a tool in germplasm conservation and plant breeding Geleta et al, (2006). During the evaluation high genetic diversity value among the sorghum accessions (landraces, breeding entries and improved cultivars) indicates that the level of genetic diversity was not influenced by breeding activities.

There are many different types of genetic markers that can be used in evaluation of germplasm for scientific research and crop improvement. This uses morphological and agronomic traits to characterize germplasm. In the past, plant breeders made selections of breeding material on the basis of morphological characteristics that were readily observable and that were co-inherited with the desired trait. For example Amsalu and Endashaw (2000) 415 sorghum accessions from Ethiopia and Eritrea were evaluated for 15 quantitative characters to determine the extent and geographical pattern of morphological variation using agro morphological descriptors. The extent of variation was highly pronounced for agronomically important characters for sorghum.

Detailed studies on genetic diversity of germplasm also performed by employing marker systems such as allozymes, RFLPs, RAPDs, AFLPs or SSRs. Both AFLPs and SSRs are more recent techniques, and have been evaluated for use in discriminating between different sorghum accessions. AFLP's, SSR's and morpho-agronomical traits markers were used to assess the genetic diversity among 45 accessions of sorghum from the eastern highlands of Ethiopia. The AFLP and SSR markers used in the study were polymorphic, and can be used to distinguish accessions of sorghum. In addition, the AFLP and SSR markers used in the study indicated that although morphological characterization is influenced by the environment and is time consuming in general, it can still be an important and 
practical means of making progress in sorghum germplasm evaluation. The low similarity value among the majority of sorghum accessions could indicate that there is a high level of genetic diversity among the test materials for these markers system. Both AFLP and SSR markers can be utilized as a method of choice for revealing genetic variation and identifying slightly different genotypes in a sorghum breeding program (Geleta et al, 2006).

\subsubsection{QTLS/Gene Mapping}

QTLs/genes associated with drought tolerance in novel stay green sorghum germplasm was identified. Evaluations of sorghum germplasm have been undertaken for biotic and abiotic stresses that limit sorghum performance and productivity in most agro-ecologies. Attributes which affect sorghum performance, adaptability yield and other factors have been assessed. Field evaluation was carried out in drought prone sorghum producing areas and other ecologies that provide the suitable screening conditions. Materials such as new source - Sorcoll 163, Sorcoll 141 and Sorcoll 146 (germplasm obtained from Ethiopian sorghum landraces) identified as a new sources of stay green trait. These lines compared to E36-1 and B35 (stay green from Uganda and Kenya) had higher green leaf area, higher chlorophyll content, higher photosynthetic rates and lower levels of leaf senesces in postflowering drought in repeated experiments (Addisie, 2010; Dagnachew, 2008). At least three F2 mapping population developed by crossing the stay green lines with a non-tolerant Sorghum genotypes (Harris et al. 2007).

National sorghum improvement programme at Melkassa Agricultural Research center (MARC) have evaluated and selected marker assisted backcrossing (MABC) derivatives from the introgression of stay-green QTLs into locally released sorghum varieties. Aeimro (2012) evaluated twenty stay-green QTLs introgression backcross generation (marker assisted backcrossing derivatives) using stay green quantitative trait loci (QTLs) sorghum lines for post flowering drought resistance. The field evaluations reveals that nine stay-green QTL introgression backcross lines (T76T1\#23xB-35-07, T76T1\#23xB-35-44, MekoxB-35-13, MekoxB-35-12, MekoxB-35-25 15,TeshalexB-3512,TeshalexB-35-13,GambellaxB-35-01 and GambellaxB-35-21) that exhibited the combination of relatively high yield potential and drought resistant traits should be promoted in areas where post flowering drought stress is a common problem.

The Ethiopian sorghum germplasm resources have proved to be useful sources for desirable genes. As a result of pointed evaluation of the collections some useful genes reported to exist in the Ethiopian germplasm are listed below (Yilma, 1991).

\begin{tabular}{|c|c|}
\hline Disease and pest resistance & Kernel traits \\
\hline $\begin{array}{ll}\checkmark & \text { Stalk borer } \\
\checkmark & \text { Downy mildew } \\
\checkmark & \text { Smuts } \\
\checkmark & \text { Bacterial streak } \\
\checkmark & \text { Anthracnose } \\
\checkmark & \text { Striga } \\
\end{array}$ & $\begin{array}{ll}\checkmark & \text { Endosperm texture } \\
\checkmark & \text { Grain colour } \\
\checkmark & \text { Threshability } \\
\checkmark & \text { Injera quality } \\
\checkmark & \text { Protein quality }\end{array}$ \\
\hline Adaptation & \\
\hline $\begin{array}{ll}\checkmark & \text { Agronomic desirability (height, maturity, panicle } \\
\text { size and shape, etc.) } \\
\checkmark \quad \text { Yield potential }\end{array}$ & \\
\hline
\end{tabular}

Table2. Predominant characteristics in the Ethiopian sorghum germplasm collection

\begin{tabular}{|c|c|}
\hline Plant & Characteristics \\
\hline Plant height & $>2.0 \mathrm{~m}$ \\
\hline Inflorescence and fruit & $>100$ days \\
\hline Days to flowering & loose to semi-loose erect branches \\
\hline Inflorescence & Purple \\
\hline Glume colour & a quarter covered \\
\hline Grain covering & $<10 \mathrm{~cm}$ \\
\hline Inflorescence exsertion & red, white, brown \\
\hline Grain & Medium \\
\hline Grain colour & mostly starchy \\
\hline Grain size & freely threshable \\
\hline Endosperm texture &
\end{tabular}

Source (Yilma, 1991) 


\subsection{Germplasm Conservation}

The purpose of conservation of germplasm in gene banks in the form of seeds is to maintain the integrity of the material conserved to the highest standard over prolonged periods of time. It is necessary to set standards based on current scientific knowledge and available technologies for the proper handling and storage of seeds in gene banks that will ensure their conservation over the longest possible time, without the need for frequent costly regeneration. Standards for routine gene bank operations and quality assurance were described by Dulloo and Engles (2003). Seeds are stored for short term as required for carry-over seeds, or for considerably longer term as required for germplasm accessions and high value seed stocks. The full benefits of any storage system are realized only when the seeds intended for storage have high initial quality. Therefore, maximum seed quality and vigor are of paramount importance in germplasm management.

Ex-situ seed storage is the most convenient and widely used method of conservation. The institute of biodiversity gene bank, sorghum collection includes 2 wild related species, 9760 landraces and 12 wild species accessions. Sorghum accessions conserved for long term storage $94 \%$ and $4 \%$ of the accessions for medium term storage. The IBPGR has recommended storing about 4000 sorghum seeds/accession for long term conservation (Upadhyaya, 2006). Abebe (2006) reported that $45 \%$ of sorghum germplasm accessions conserved in Ethiopian Biodiversity Institute with detailed passport data including the collection regions, localities and altitude zones of these collections.

\section{TYPES OF CONSERVATION}

Active collections refer to collections kept for medium term, which are immediately available for distribution for utilization and multiplication. Active collections are kept in conditions, which ensure that the accession viability remains above $65 \%$ for $10-20$ years. Different combinations of storage temperature and moisture content can provide this longevity (IPGRI 1996). Active collections of sorghum in Institute of Biodiversity gene bank stored in standard aluminum cans and the equilibrium moisture content for these samples ranges between 7 and 10\%, relative humidity in between $20-30 \%$ and stored under condition $4{ }^{\circ} \mathrm{C}$. Ideally, these are maintained in sufficient quantity to be available on request (Hamilton et al. 2003).

Base collections refer to collections kept for long term, solely for 'posterity', and are not drawn upon except for viability testing and subsequent regeneration. The accessions in base collection should be distinct, and in terms of genetic integrity, as close as possible to the sample provided originally. The base collections of sorghum germplasm are maintained in vacuum packed standard aluminum foil pouches at $3-7 \%$ seed moisture content, with initial seed viability above $85 \%$. The storage conditions maintained for both the collections are preferred standards for international gene banks. Base collections are stored under conditions $-20^{\circ} \mathrm{C}$ ensuring long-term viability of material more than 50 years as a security to the active collection. Hamilton et al. (2003) have described considerations for improved conservation and utilization concepts and strategies.

\subsection{Safety Back-Up}

Ethiopia has none of the sorghum accessions backed up and even for other crop collections inside the country. ICRISAT reported that 5000 landraces and cultivars of Ethiopian sorghum accessions backed up at ICRISAT center. In early times Ethiopian Biodiversity Institute planned the collection of unique sorghums accessions" and other crops should be duplicated/backed-up and stored at least two sites chosen on the basis of long term security. In addition to this in situ conservation has been considered as backup and complementary strategy to ex situ conservation and a model for its implementation has been suggested (Dahlberg, 2000).

\subsection{Regeneration of Germplasm}

Regeneration of germplasm is one of the most crucial processes in gene bank management. It is costly in terms of resources and time, and it involves the risk to genetic integrity. The methods employed for regeneration vary considerably according to the crop species and its reproductive system (inbreeding or out-breeding) (Upadhyaya , 2008). In crops like sorghum optimum plant stand and suitable pollination control measures are required for maintaining genetic integrity.

Regeneration activities are regularly performed to effectively maintain the quality of the stored germplasm collections. Complimentary activities such as timely viability testing during storage, selection of suitable regeneration environments, use of appropriate sampling strategies, use of 
adequate isolation distances, and proper handling of regenerated materials are followed according to internationally accepted standard procedures for each specific crop type. A reliable power supply is also critical. The Ethiopian gene bank has therefore an independent power supply in the form of a stand by generator in case of shorter power cuts or in case of a more severe national energy crisis. To date 13336 accessions have been regenerated and over 7400 accessions need immediate regeneration. In case of sorghum 3738 accessions regenerated and 5510 accessions are in need of regeneration currently (<85percent viability) (IBC, 2007).

Limited capacity is hindering this. However, a plan is now in place to complete the regeneration within 5 years. Urgently required activities include viability tests and collaboration with partners to secure access to land in a range of agro-ecologies to carry out the multiplication and rejuvenation. The regional governments could provide sites in different agro ecological zones of the country. The research activities being carried out and new academic institutions being established could be an opportunity to address the problem of regeneration of threatened ex situ accessions. There is an opportunity for regional collaboration and cooperation as well as support from the international community in the regeneration and conservation of germplasm held ex situ (IBC, 2007).

\subsection{Germplasm Utilization}

The ultimate goal of conservation is to make germplasm of plant genetic resources available for utilization so as to contribute to the livelihoods of the Ethiopian people. Ethiopia has had limited success with the utilization of the conserved germplasm. Rather, other countries have better benefited from Ethiopian germplasm. In this regard, fair and equitable sharing of benefits arising from the use of Ethiopia's germplasm needs to be recognized as clearly stated in Article 15 and 19 of the Convention on Biological Diversity (FAO, 2006).

To enhance the implementation of conservation and utilization activities there is a need for national and regional collaboration among institutions. With respect to this, the National Information Sharing Mechanism and awareness raising about the conserved germplasm is an opportunity to boost the utilization of the country plant genetic resources. The international community should put this into its priority agenda in order to strengthen Ethiopia's capacity to conserve and use plant genetic resources in a sustainable way. Indigenous germplasm is the basic source of genetic materials for national crop improvement programmes (FAO, 2006).

The national germplasm collections in Ethiopian Biodiversity Institute gene bank comprise over 60000 accessions belonging to more than 200 plant species from which about 80400 seed sample have been distributed to users. The use of accessions in plant breeding programmes and the subsequent development of released cultivars are the most recognized uses of genetic resources. Over 9772 accessions of Ethiopian sorghum were collected and about 8667 numbers of seed samples have been distributed from the gene bank for breeders, national research and crop improvement programme and other users. More than 300 accessions of minor millet and 5000 sorghum accessions of Ethiopian material are held by ICRISAT, of which the sorghum line E 35-1 has been selected from zera-zera landrace of Ethiopia. The E-35-1 line has now been introduced for direct cultivation and is used in breeding programmes in many countries (IBC, 2007).

Utilization has been primarily limited to agronomically important and in some cases, wild sources of germplasm. For example, the major germplasm sources utilized so far in varietal improvement include temperate lines of zera zera from Ethiopian sorghum has become widespread in the development of new, superior hybrids because of superior yield potential and grain quality. The classic example of germplasm utilization in sorghum has been the Texas A\&M-USDA Sorghum Conversion Program. Till date 633 converted lines have been released globally Rosenow et al. (1995).

The stable resistant sources for shoot fly and stem borer, IS 18551 in Ethiopia have been used to impart resistance. The high-lysine sorghum lines, IS 11167 and IS 11758 from Ethiopia were used in the breeding program for transferring the gene to a desirable agronomic background. Some promising high-lysine derivatives with plump grain have been obtained (Reddy et al., 2006).

During 1990s, most of the hybrids tested in all-India trials were based on 296A with various restorers but could not make any remarkable dent for grain yield over CSH9. Though there was no significant grain yield improvement, useful diversification for early maturity and higher fodder yield has been achieved with the release of CSH13 and CSH14. The fodder yield of CSH13 is $40 \%$ more than that of CSH9 although its grain yield is marginally improved. The R-line of this hybrid, RS 29 that 
contributes to heterosis for fodder yield is developed from SC108, an American elite line and SPV 126 (a tall mutant of CS 3541). Another hybrid, CSH14, is about 10 days earlier than CSH9 maintaining the same level of grain yield. The need for diversification of female parent was felt in view of seed production problems and stagnating yield level. Another high yielding hybrid, CSH16 was developed from new ms line 27A, and R-line C 43. This hybrid showed further improvement in grain mold tolerance as the new genes from Ethiopian germplasm line IS 23549 was introduced into its R-line. The R-line has very compact panicle. In contrast to $296 \mathrm{~B}$, ms line $27 \mathrm{~A}$ of this hybrid is long and has loose panicles with bold and round seed like that of post-rainy season genotype that has consumer preference (Reddy et al., 2006).

Besides the utilization of germplasm in ongoing research in different institutes, some sorghum germplasm accessions of Ethiopia supplied from the ICRISAT gene bank have been directly released as cultivars (Table 3). Among these IS 18758, a popular landrace from Ethiopia belonging to the hybrid race guinea-caudatum WG zerazera. It has been released as a variety in Burundi (as Gambella 1107) and Burkina faso (as E 35-1). This landrace has proved to be a source of useful traits such as excellent grain quality, high grain yield potential, tan plant, straw glume color, resistant to leaf diseases, tolerance to grain weathering and desirable plant type. It has been extensively used in sorghum breeding programs at ICRISAT and in national breeding programs, and dominates the germplasm base of elite materials (Reddy et al., 2006).

Table3. Sorghum germplasm accessions released directly as cultivars in Ethiopia and other countries

\begin{tabular}{|c|c|c|c|c|}
\hline Accession No. & Country origin & Year of release & Country of release & Released name \\
\hline IS 30468 & Ethiopia & 1980 & India & NTJ 2 \\
\hline IS 18758 & Ethiopia & 1983 & Burkina Faso & E-35-1 \\
\hline IS 9302 & South Africa & 1980 & Ethiopia & ESIP 11 \\
\hline IS 9323 & South Africa & 1984 & Ethiopia & ESIP 12 \\
\hline IS 23520 & Ethiopia & 1989 & Zambia & Sima \\
\hline IS 18758 & Ethiopia & 1990 & Burundi & Gambella 1107 \\
\hline IS 23496 & Ethiopia & 1995 & Tanzania & Pato \\
\hline
\end{tabular}

Source (Reddy et al., 2006)

Improved varieties; early maturing and well adapted to the dry land areas of Ethiopia, high tannin content and very good for local drink, good quality for making injera with high preference of customers etc. are identified by national agricultural research system. Most of them also combine high yielding, earliness and disease and pest resistance. Some of them are also resistant to striga, the parasitic weed a threat to sorghum production in many African and Asian countries. The sorghum varieties for the lowland dry land areas altitude up to 1600 above sea level and widely utilized by Ethiopian farmers is given in the following table (Kidane et al, 2009).

Table4. List of some of sorghum varieties utilized in dry lands of Ethiopia

\begin{tabular}{|c|c|c|}
\hline Sorghum Varieties & Main description & Main adaptation areas \\
\hline Gambela-1107 & $\begin{array}{l}\text { Yield potential ranges from } 2.5-3 \mathrm{t} / \mathrm{ha} \text {. } \\
\text { Utilization: it is good for injera making. It is } \\
\text { relatively resistant to most pest and diseases } \\
\text { of sorghum }\end{array}$ & $\begin{array}{c}\text { with more than } 600 \mathrm{~mm} \text { of rainfall } \\
\text { annually in semiarid areas } \\
\text { including Gambella, Yabello, Jijga } \\
\text { Kobo, }\end{array}$ \\
\hline 76-T1-23 & $\begin{array}{l}\text { It is very early maturing and fits well to the } \\
\text { dry semi-arid areas. Utilization: good quality } \\
\text { for making injera with high preference of } \\
\text { customers }\end{array}$ & $\begin{array}{c}\text { North Wello in Kobbo Alamata } \\
\text { area, Cheffa area, north Shewa and } \\
\text { Meiso area. }\end{array}$ \\
\hline Melko-1 & $\begin{array}{l}\text { Early maturing and drought and heat resistant. } \\
\text { Utilization: white seed with good injera } \\
\text { making quality. High biomass production }\end{array}$ & $\begin{array}{l}\text { Dry semi-arid areas with short } \\
\text { growing season. It is released for } \\
\text { north Shewa, Kobbo and other } \\
\text { similar areas. }\end{array}$ \\
\hline Gubiye \& Abshir & $\begin{array}{l}\text { Similar characteristics to Melko- } 1 \text { in terms } \\
\text { maturity, drought and heat resistance and } \\
\text { utilization. Additional attribute is its } \\
\text { resistance to the parasitic weed striga. }\end{array}$ & $\begin{array}{l}\text { north Shewa, Kobbo and Meiso } \\
\text { areas and well adopted by farmers } \\
\text { and other dry-semi-arid areas }\end{array}$ \\
\hline Macia & $\begin{array}{l}\text { High yield potential about } 3 \text { t/ha, The variety } \\
\text { stays green has broad leaves with juicy thick } \\
\text { stem and good quality crop residue used for } \\
\text { livestock fodder. }\end{array}$ & $\begin{array}{l}\text { It is widely adapted in semi-arid } \\
\text { areas and short growing areas with } \\
\text { elevation of less than } 1600 \mathrm{~m}\end{array}$ \\
\hline
\end{tabular}


Sorghum Genetic Resource Collection, Evaluation, Conservation and Utilization in Ethiopia: A Review

\begin{tabular}{|c|c|c|}
\hline Seredo & $\begin{array}{c}\text { Bird resistant, drought tolerant, have high } \\
\text { tannin content and very good for arekie } \\
\text { making (local drink) }\end{array}$ & $\begin{array}{l}\text { All dry semiarid of the lowlands } \\
\text { particularly in the rift valley areas } \\
\text { where problem is a major } \\
\text { constraint for sorghum }\end{array}$ \\
\hline Teshale & $\begin{array}{c}\text { Early, days to maturity } 100-120 \text {, yield } t / \text { ha } \\
3.0-4.5 \text {, high biomass production used for } \\
\text { feed }\end{array}$ & $\begin{array}{c}\text { Dry lowland with altitude less than } \\
1600 \mathrm{~m} \text {, lowlands of north Wello } \\
\text { and north Shewa }\end{array}$ \\
\hline WSU-387-Melkam & $\begin{array}{l}\text { Early, days to maturity } 118 \text {, yield t/ha } 3.7- \\
5.8 \text {, high biomass production used for feed }\end{array}$ & $\begin{array}{c}\text { Dry lowland with altitude less than } \\
1600 \mathrm{~m} \text {, lowlands of north Wello } \\
\text { and north Shewa }\end{array}$ \\
\hline Area Yeju & $\begin{array}{l}\text { Early, days to maturity } 120, \text { yield t/ha 5.0, } \\
\text { high }\end{array}$ & $\begin{array}{l}\text { Lowlands of Wello and similar } \\
<1600 \mathrm{~m} \text {, dry semiarid areas }\end{array}$ \\
\hline Raya & Early, days to maturity 130 , yield t/ha 3.03 .8 , & $\begin{array}{l}\text { Lowlands of Wello, SIrinka area } \\
<1600 \mathrm{~m} \text {, dry semiarid areas }\end{array}$ \\
\hline Misikir & Early, days to maturity 126 , yield t/ha $4, .1$ & $\begin{array}{l}\text { Lowlands of Wello, SIrinka area } \\
<1600 \mathrm{~m} \text {, dry semiarid areas }\end{array}$ \\
\hline Girana-1 & Early, days to maturity 122 , yield t/ha 4,1 & $\begin{array}{l}\text { Lowlands of Wello, SIrinka area } \\
<1600 \mathrm{~m} \text {, dry semiarid areas }\end{array}$ \\
\hline Gedo & Early, days to maturity 134 , yield t/ha 4,1 & $\begin{array}{l}\text { Lowlands of Wello, SIrinka area } \\
<1600 \mathrm{~m} \text {, dry semiarid areas }\end{array}$ \\
\hline Abshir & Days to maturity $100-120$, yield t/ha $1.5-2.5$ & $\begin{array}{l}\text { Lowlands of Wello, SIrinka area } \\
<1600 \mathrm{~m} \text {, dry semiarid areas }\end{array}$ \\
\hline Gobie & $\begin{array}{c}\text { Days to maturity } 100-120 \text {, yield t/ha } 1.9 \text { - } \\
2.7 \text {, striga resistant }\end{array}$ & $\begin{array}{l}\text { Lowlands of Wello, SIrinka area } \\
<1600 \mathrm{~m} \text {, dry semiarid areas }\end{array}$ \\
\hline Birhan & $\begin{array}{c}\text { Days to maturity } 100-120, \text { yield t/ha } 4.0, \\
\text { striga resistant }\end{array}$ & $\begin{array}{l}\text { Lowlands of wello, SIrinka area } \\
<1600 \mathrm{~m} \text {, dry semiarid areas }\end{array}$ \\
\hline Harmat & $\begin{array}{l}\text { Days to maturity 100-120, yield t/ha } 1.5-2.5 \text {, } \\
\text { striga resistant }\end{array}$ & $\begin{array}{l}\text { Lowlands of Wello, SIrinka area } \\
<1600 \mathrm{~m} \text {, dry semiarid areas }\end{array}$ \\
\hline MACIA & $\begin{array}{l}\text { Days to maturity } 110-130, \text { yield t/ha } 3.0-4.5 \text {, } \\
\text { high yielding, malt type }\end{array}$ & $\begin{array}{l}\text { Lowlands of Wello, SIrinka area } \\
<1600 \mathrm{~m} \text {, dry semiarid areas }\end{array}$ \\
\hline
\end{tabular}

Source: Ministry of Agriculture and Rural Development (MOARD 2008, crop variety register issue No 11, Addis Ababa, Ethiopia

\section{SUMMARY}

Crop plant genetic resources including landraces, old and new cultivars, etc., are vital to crop improvement. These were used in research to develop improved cultivars that has resulted in increase of productivity and production considerably of various crops. The need for collecting and conserving germplasm was realized during 1960s, when there was threat of loss of landraces due to large adoption of improved varieties.

Ethiopia is one of the richest genetic resource centers in the world in terms of crop diversity. Crop plants such as coffee (Coffea arabica), safflower (Carthamus tinctorius), tef (Eragrostis tef), noug (Guizotia abyssinica), anchote (Coccinia abyssinica), enset (Ensete ventricosum), are known to have originated in Ethiopia. Sorghum is among the four crops widely grown food crops in the world. Very high sorghum genetic diversity is found in Ethiopia. Ethiopian Biodiversity Institute is a major repository for sorghum germplasm collection and conservation with a total of 9772 accessions from different agro-ecological zones of the country. The fundamental objective of collecting plant genetic resource is to capture the maximum amount of genetic variation in the smallest number of samples.

In the past, plant breeders made selections of breeding material on the basis of morphological characteristics that were readily observable. Molecular and biochemical markers which are neutral to environment variation also be used for evaluation. Improved varieties; early maturing and well adapted to the dry land areas of Ethiopia, high tannin content and very good for local drink, good quality for making injera with high preference of customers etc are identified by national agricultural research system for sorghum improvement.

Incomplete passport data, lack of safety backups, sampling the probable genetic diversity, size, documentation are the most critical deficiencies in Ethiopian Biodiversity Institute. Since sorghum is grown in 13 of the 18 major agro-ecological zones, the number of collected accessions cannot represent the total sorghum genetic resource in the country. It was also assumed that most of the 
accessions were collected along main roads. On the basis of these limited germplasm collection from marginal sites has been observed.

\section{REFERENCES}

[1] Abe Shegro (2010). Biodiversity in plant, grain and nutritional characteristics of sorghum [Sorghum bicolor (L.) Moench] accessions from Ethiopia and South Africa. PhD Dissertation, Free state University South Africa, 164pp.

[2] Abebe Demissie (2006). Regional strategy for the ex situ conservation of plant genetic resources: Eastern Africa. Eastern Africa Plant Genetic Resources Network (EAPGRN), Entebbe, Uganda.

[3] Addisie Yalew (2010). Evaluation of Sorghum (sorghum bicolor) genotypes for post flowering drought resistance (stay-green trait). MSc. Thesis, Addis Ababa University, Ethiopia.

[4] Aemiro Bezabih (2012). Evaluation of stay-green Quantitative Trait Loci (QTLs) introgression sorghum (sorghum bicolor (1.) moench) lines for post flowering drought resistance at Kobo, North Eastern Ethiopia. MSc. Thesis, Haramaya University, Ethiopia

[5] Allard RW (1970). Population structure and sampling methods. In: Frankel OH and Bennett E (Eds), Genetic Resources in Plants. Blackwell, Oxford, Pp. 97-107.

[6] Amsalu Ayana and Endashaw Bekele (2000). Geographical patterns of morphological variation in sorghum (Sorghum bicolor (L.) Moench) germplasm from Ethiopia and Eritrea: Quantitative characters. Euphytica, 115: 91-104.

[7] Beyene Seboka and Hintum TV (2006). The dynamics of on-farm management of sorghum in Ethiopia: Implication for the conservation and improvement of plant genetic resources. Genetic Resources and Crop Evolution, 53: 1385-1403.

[8] Dagnachew Bekele (2008). Genetic diversity study in sorghun germplasm accessions collected from the major drought prone areas of Ethiopia based on quantitative and qualitative traits. MSc Thesis, Addis Ababa University Ethiopia.

[9] Dahlberg JA and Spinks MS (1995). Current status of the US sorghum germplasm collection. International Sorghum and Millets Newsletter, 36:4-12.

[10] Dahlberg JA (2000). Classification and characterization of sorghum. In. sorghum, origin, history, technology, and production. (Eds.) C. Wayne Smith and Richard A. Frederiksen. Texas A\&M University. John Wiley and Sons, Inc.

[11] Dulloo E and Engles JM (2003). Gene bank standards and quality assurance. In A guide to effective management of germplasm collections (Engles JM and Visser L, Eds.). Pp. 140-146. IPGRI Handbooks for gene banks No. 6. Rome, Italy: International Plant Genetic Resources Institute.

[12] Eberhart SA, Bramel-Cox PJ and Prasada Rao KE (1997). Preserving genetic resources. In Proceedings of the International conference on genetic improvement of sorghum and pearl millet, 22-27 September 1996, Lubbock, TX. Pp. 25-41

[13] FAO (1983). International undertaking on plant genetic resources. Rome, FAO of the United Nations.

[14] FAO (1996). Country report to the FAO international technical conference on plant genetic resources Leipzig, Germany, 17-23 June. FAO, Rome.

[15] FAO (2006). International treaty on plant genetic resources for food and agriculture. FAO, the United Nations.

[16] Geleta Nemera, Labuschagne MT and Viljoen CD (2006). Genetic diversity analysis in sorghum germplasm as estimated by AFLP, SSR and morpho-agronomical markers. Biodiversity and Conservation, 15:3251-3265.

[17] Gopal GN, Rao K, Reddy BVS and Prasada RKE (2002). Geographic distribution of basic and intermediate races in the world collection of sorghum germplasm. International Sorghum and Millets Newsletter, 43:15-17.

[18] Hamilton SH, Engles JMM and Van Hintum T (2003). Considerations for improved conservation and utilization concepts and strategies. In: A guide to effective management of germplasm collections (Engles JMM and Visser L, Eds.). Pp. 43-59. IPGRI Handbooks for Genebanks No. 6. Rome, Italy: International Plant Genetic Resources Institute.

[19] Harris K, Subudhi PK, Borrell A, Jordan D, Rosenow D, Nguyen H, Klein P, Klein R, Mullet R (2007). Sorghum stay-green QTL individually reduce post-flowering drought-induced leaf senescence. Journal of Experimental Botany, 58: 327-338.

[20] Hoa T (2010). Overview of Vietnam Rubber Industry and Prospects of Development by 2020, Proceedings of the $9^{\text {th }}$ Asian Workshop on Polymer Processing in Vietnam. December, 7-10, 2010.

[21] IPGRI (1993). Diversity for Development. Rome, IPGRI. 
[22] IPGRI (1996). Report of the internally commissioned external review of the CGIAR gene bank operations. Rome, Italy, International Plant Genetic Resources Institute.

[23] Kameswara RN and Sastry DVSR (1998). Seed quality considerations in germplasm regeneration. In Regeneration of seed crops and their wild relatives Proceedings of a Consultation Meeting, 4-7 December 1995, ICRISAT, Patancheru, India (Engles JMM and Ramanatha Rao R, Eds.). Pp.144-149. Patancheru 502 324, Andhra Pradesh, India: International Crops Research Institute for the Semi-Arid Tropics.

[24] Kidane Georgis, Alemneh Dejene, Meshack Malo (2009). Agricultural based livelihood systems in dry lands in the context of climate change. Inventory of adaptation practices and technologies of Ethiopia. Institute of Agricultural Research, Addis Ababa.

[25] Marshall DR and Brown AHD (1975). Optimum sampling strategies in genetic conservation. In: Frankel $\mathrm{OH}$ and Hawkes JG. (Eds). Pp. 53-80. Crop Genetic Resources for Today and Tomorrow. Cambridge University Press, Cambridge.

[26] MOARD. (Ministry of Agriculture and Rural Development) (2008). Plant and animal health regulatory directorate, crop variety register issue No 11, Addis Ababa, Ethiopia.

[27] Prasada RKE, Gopal RV and Stenhouse JW (1995). Sorghum genetic resources at ICRISAT Asia Center. International Sorghum and Millets Newsletter, 36:15-19.

[28] Reddy BVS, Ashok KA, Sanjana P and Elangovan M (2006). Sorghum germplasm, diversity and utilization. Patancheru 502 324. Andhra Pradesh, India. International Crops Research Institute for the Semi-Arid Tropics (ICRISAT).

[29] Roberts EH (1984). Monitoring seed viability in genebanks. In Seed management techniques for genebanks (Dickie JB, Linington S and Williams JT Eds.). Pp. 268-277. Rome, Italy, International Board for Plant Genetic Resources.

[30] Rosenow DT and Dalhberg JA (2000). Collection, conversion and utilization of sorghum. In Sorghum, origin, history, technology and production, (Smith CW and Frederiksen AR, Eds.). Pp. 309-328. Wiley Series in Crop Science. New York, John Wiley \& Sons.

[31] Rosenow DT, Dahlberg JA, Paterson GC, Clark LE, Sotomayor-R'os A, Miller FR, Hamburger AJ, Madera-Torres P, Quiles-Belen A and Wood fin CA (1995). Release of 50 converted sorghum lines and 253 partially converted sorghum bulks. International Sorghum and Millets Newsletter, 36:19-31.

[32] Upadhyaya HD, Gowda CL and Sastry DV (2008). Plant genetic resources management: collection, characterization, conservation and utilization. Journal of SAT Agricultural Research, 6:1-16.

[33] Widrlechner MP (1998). Managerial tools for seed regeneration. In Regeneration of seed crops and their wild relatives. Proceedings of a Consultation Meeting, 4-7 December 1995, ICRISAT, Patancheru, India (Engles JMM and Ramanatha Rao R, Eds.). Pp. 133-139. Patancheru 502 324, Andhra Pradesh, India, International Crops Research Institute for the Semi-Arid Tropics.

[34] Yilma Kebede (1991). The role of Ethiopian germplasm resources in the national breeding programme. In: Engles JM, Hawkes JG and Worede Melaku, Eds.). Pp. 315-322, Plant genetic resources of Ethiopia, Cambridge University Press, Cambridge, UK.

Citation: Brikti Ferede, Wondimeneh Taye, "Sorghum Genetic Resource Collection, Evaluation, Conservation and Utilization in Ethiopia: A Review" International Journal of Research Studies in Agricultural Sciences (IJRSAS), 2019; 5(12), pp. 35-45, http://dx.doi.org/10.20431/2454-6224.0512005

Copyright: (C) 2019 Authors. This is an open-access article distributed under the terms of the Creative Commons Attribution License, which permits unrestricted use, distribution, and reproduction in any medium, provided the original author and source are credited. 